\title{
数值シミュレーションによる日本堤システムの 洪水調節機能の評価
}

\author{
石川忠晴 ${ }^{1} \cdot$ 赤穗良輔 $^{2} \cdot$ 小林裕貴 ${ }^{3}$ \\ 1 フェロー会員＼cjkstart東京工業大学名誉教授（†215-0035 藤沢市片瀬海岸 2-4-15） \\ E-mail:workishikawa0612@yahoo.co.jp \\ 2 正会員 岡山大学大学院助教 環境生命科学研究科（下700-8530 岡山市北区津島中 3-1-1) \\ ${ }^{3}$ 非会員 株式会社エスイー 新製品開発部（†163-1343 新宿区西新宿 6-5-1）
}

\begin{abstract}
江戸市街地を水害から守るために 17 世紀初頭に設置された日本堤の水理機能を, 汇濫数值シミュレー ションにより検討した. 江戸時代の地形条件および水文条件に関寸る数值データは存在しないので, 堤防 高と汇濫原地形を明治 42 年の測量図をもとに作成し, 洪水波形は明治 44 年の全国直轄河川治水計画にお ける荒川計画流量と水文水質データベースに掲載されている 2007 年 9 月洪水の観測結果を組み合わせて 3 種類設定した。シミュレーション結果によれば，従来考えられていた上流低地の遊水量は意外に小さく， 日本堤での塞き上げに伴う下流水面勾配増大による隅田川下流への流量増と, 綾瀬川合流部を経由した中 川低地水田地帯への氾濫水誘導が日本堤の主たる機能であると考えられた。また，このような “水の逃げ 道を考慮した遊水機能”により. 日本堤の越水破堤の危険性は小さかったものと考えられる.
\end{abstract}

Key Words: evaluation of historic river works, flood control, Edo Era, numerical simuration

\section{1. はじめに}

日本堤は江戸時代初期の元和 6 年（1621年）に荒川下 流部（現在の隅田川）の右岸に建設された治水施設であ る. 現在の浅草 7 丁目付近の高台と北西の丘陵とを結ぶ 堤高 $3 \mathrm{~m}$ 程度の盛土で，江戸市街地への荒川洪水の浸入 を防いでいた ${ }^{1)}$. 大正 13 年（1924 年）に岩淵水門が完 成し，隅田川に荒川からの洪水が流入しなくなった時点 で役割を終え，昭和 2 年（1927年）に撤去された。

日本堤は荒川右岸の洪積台地と左岸の墨田堤および熊 谷堤から構成される長大な遊水地の最下流にあり, 洪水 を塞き上げる役割を持っていた ${ }^{1), 2)}$. しかし日本堤の直 下流は新吉原や浅草などの市街地であり，高々 $3 \mathrm{~m}$ の土 堤で荒川の洪水を全て受け止めるのはかなり危険ではな かったか. この素朴な疑問が本研究の動機である.

実際，1629 年に荒川が入間川筋に付け替えられ ${ }^{3)}$ ，そ の下流部にあたる隅田川の洪水ポテンシャルは著しく増 大している. 日本堤は土堤であるから，遊水地の水位が 上昇して越水が生じた場合は容易に破堤し，下流部の水 害はかえって激化する恐れもあった。このことを江戸時 代の土木技術者が考えなかったとは思えない.

当時の河川工事は全て人力によっていたので築堤の規 模は小さく, 現代のように河川敷内に洪水を封じ込める 治水方式は採用できなかった。 しかし水準測量の技術は
十分発達していたことから, 築堤により生じる微妙な水 位差によって汇濫水を誘導するという方法が考えられて いた可能性がある.

そこで本研究では，日本堤を要とする江戸市街地北側 の治水施設を，単なる貯留施設としてではなく，一群の 築堤により洪水を誘導し制御する広域的仕掛けと捉え, 数值シミュレーションにより氾濫水の流動特性を推測し, システムとしての堤の効果を評価するとともに, 当時の 土木技術者の治水施設設計の思想について考察した. な お墨田堤，千住堤，熊谷堤など河川沿いの堤防は自然堤 防を拡充したものと考えられ，築造年代は不明である. (a) 安政江戸図 (1859)

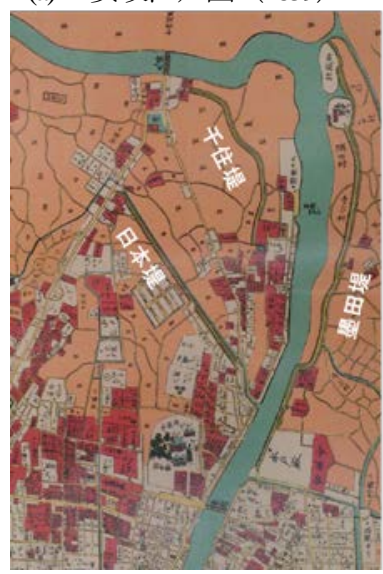

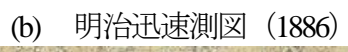

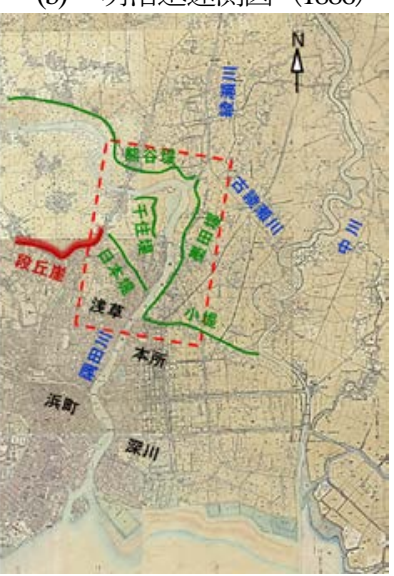

図-1日本堤システムの配置 


\section{2. 研究対象領域の概要}

図-1 (a) に安政 6 年（1859 年）作成の江戸市街絵図を, (b) に明治 19 年（1886 年）作成の迅速測図を示す。 (b) に赤い破線で示寸部分が (a)の範囲に相当する.

安政江戸図には日本堤，隅田堤，千住堤という3 本の 堤防が緑の太線で記入されており，それらが漏斗状の狭 窄部を形成して上流からの洪水を塞き上げていたことが 想像される. 日本堤の南側は浅草の寺社地区と市街地で ある. また日本堤の「堤」という字の横の区画は，明暦 の大火（1657 年）の後に人形町から移転した吉原遊郭 である. 日本堤の北側と墨田堤の東側は水田地帯である. 日本堤北西端は日光 - 奥州街道（現在の国道 4 号線）に 接続しており, 南東端も河岸の高台に接続していた.

迅速測図には本研究で考慮する堤防を緑色, 台地の崖 を茶色で示し、主要な地名を黒字で記入してある．なお 国交省資料 ${ }^{2)}$ によれば，安政江戸図にある“水戸殿”（水 戸藩下屋敷）の下流側から東方に向から水路の北側に小 型の堤があり，ここでは便宜的に「小堤」と記している. 汇濫計算の範囲は, 現在の隅田川 $21 \mathrm{KP}$ (図の外) から 東京湾までとした．ただし荒川の汇濫水が到達しないと 考えられる高地と中川左岸は除いている。計算には三角 形非構造格子を用いた浅水流モデル4,5を使用した.

\section{3. 計算条件}

\section{(1) 汇濫原の地盤高}

図-1 (b) に概ね対応する区域の GIS 標高データ（2015 年作成 $5 \mathrm{~m}$ メッシュ) のを図-2 に示寸，江戸時代から現 代までに次のような地形変化が生じている. (1) 地下水 汲み上げによる地盤沈下，(2) 荒川放水路の開削，(3) 道 路・鉄道などの盛り土，(4)埋め立てによる海岸線の変化.

それらを考慮して GISデータを以下のように補正した。 (1) : 明治 42 年（1909 年）の測量図には図-3 左に示すよ うに標高值が記入されているので GIS データとの差から 標高変化量を求めた. その結果を図-3 右に示寸.この 值を空間的に内挿して GIS データに加え計算に用いた.

(2) : 荒川放水路両岸の標高から河川敷内標高を内捙した. (3) : 地図にある道路・鉄道と GIS データを照合し, 周囲 地盤から内插して, 帯状の高地をできる限り除去した. ただし旧街道は周囲地盤から $1 \mathrm{~m}$ 高いものと仮定した。 (4) : 隅田川河口には現在は多数の埋立地が存在し江戸期 の海底地形は不明なので、ここでは当時の絵図から海岸 線を推定し, 便宜的に1/570 の海底勾配を仮定した.

\section{(2) 河道地形}

図-1 (b) と図-2 において隅田川平面形状がほとんど違

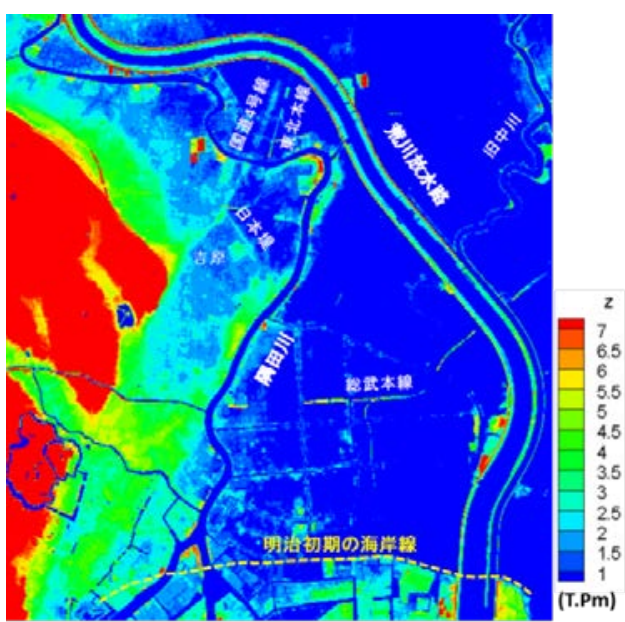

図-2 GIS 標高データ（2015年作成 $5 m$ メッシュ）

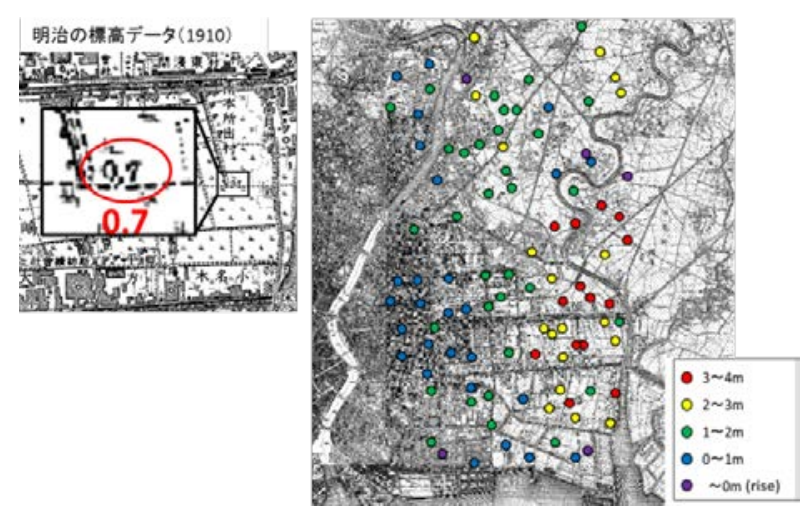

図-3 地盤沈下量の推定結果

わないことから，隅田川河道地形については 2015 年作 成の河道断面図（東京都提供）を内括て用いた。一方， 当時の中川の河道形状については情報がなかったので, 明治 42 年測量図から平面形状を定め, 断面形は矩形々 した．隅田川湾曲部で合流する綾瀬川と，そこから東側 に分離する水路（古綾瀬川）についても同様の取り扱い とした.

\section{(3) 堤防高}

数值シミュレーションでは図-1 (b) に緑字で記した堤 防を考慮した. 日本堤の比高は $3 \mathrm{~m}$ 程度と考えられてい るが ${ }^{1)}$, 図-4(a)に示すように両端は高台に接続していた ので，周囲地形をもとに天端標高を T.P. 4.5m に設定し た. 日本堤縦断方向の地盤標高と堤防天端高を図-4(b) に示寸．地盤が低い 部分での堤高は $3 \mathrm{~m}$ となっている. (a) 標高図

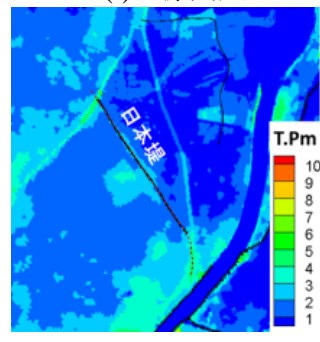

(b) 縱断図

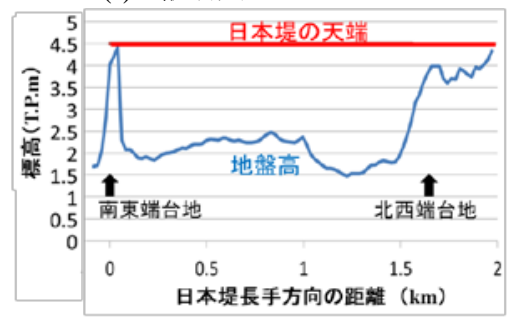

図-4 日本堤の天端高の仮定 
墨田堤と熊谷堤の高さについての資料はなかつたが, 明治 42 年測量図（Internet 上の画像データ）を極限まで 拡大すると，堤防位置に”+2.5”のように通常の地盤標高 と異なる形式で数字が書かれており（図-5 左），これ を盛土の比高と考えた。図-5 右の黄色の三角はそれら の位置を示している．熊谷堤には同図の上流側にさらに 3 点（計 5 点）の比高の記載がある. なお図中の赤の菱 形は熊谷堤下流端と墨田堤上流端である。 そこで墨田堤

（隅田川左岸から上流の綾瀬川左岸に接続する）につい ては平均河床と平行に上述の点を通る直線を引き，天端 高とした。一方，熊谷堤のある上流部では河道の蛇行が 著しいので，大局的な河道軸線に投影した平均河床縦断 形と平行になるように，5 か所のデータ（黄色三角）と 堤防接続部（赤菱形）から最小二乗法で天端高を設定し た。 以上から得られた堤防天端の縦断図を図-6に示す。 青線が地盤高，赤線が仮定した堤防天端の縦断形である。

千住堤と水戸殿からの小堤については資料が全くない が，周囲の地形への接続を考え，それぞれ T. P. $2.9 \mathrm{~m}$ と T.P. $3.2 \mathrm{~m}$ とした.

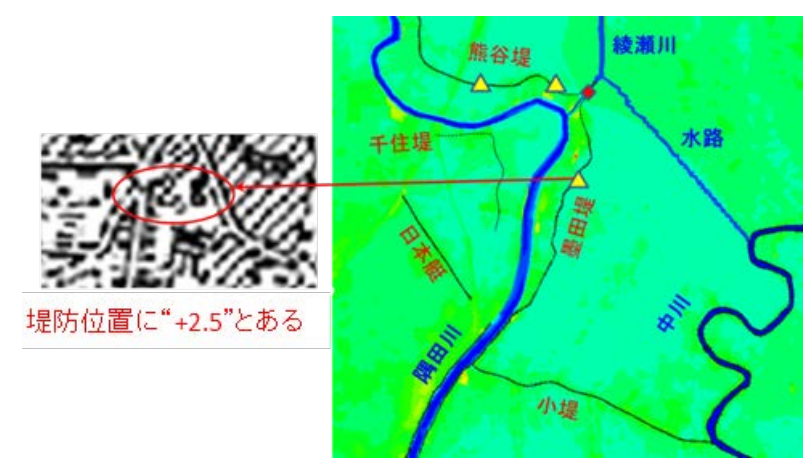

図-5 堤防の比高の記述

(a) 墨田堤

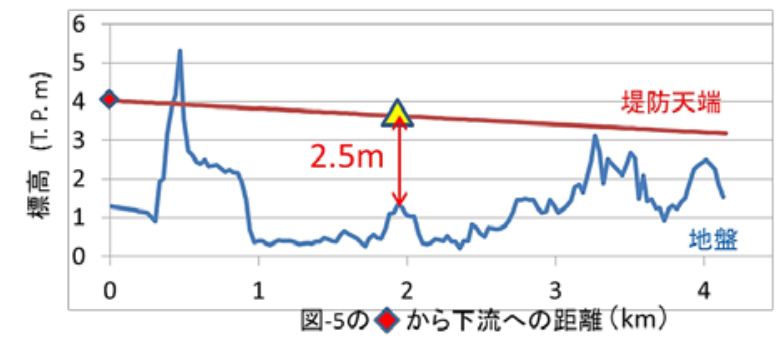

(b) 熊谷堤

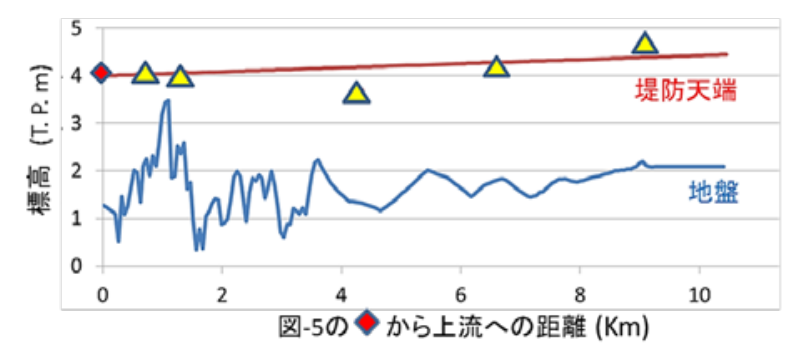

図-6 堤防天端の縦断形

\section{(4) 洪水ハイドログラフ}

明治 44 年（1911 年）の全国直轄河川治水計画 》によ れば，荒川下流部岩㴊地点（現在の隅田川流頭部）にお ける計画流量は 90,000 立法尺と記されている。これを $\mathrm{m}-\mathrm{s}$ 単位に変換すると $2,500 \mathrm{~m}^{3} / \mathrm{s}$ となり, 現在の基本高水 流量である $13,100 \mathrm{~m}^{3} / \mathrm{s}$ や，岩淵地点の計画高水流量

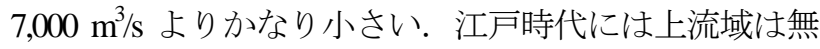
堤ないし輪中堤しかなかったので ${ }^{3)}$ ，荒川が入間川笳に 付け替えられてから河川氾濫が頻発した．そのため下流 部の洪水ピーク流量は現在よりかなり小さかったと想像 される. 一方，岩淵水門で荒川から締め切られた現在の 隅田川計画流量は, 残流域と新河岸川からの流出の $2,100 \mathrm{~m}^{3} / \mathrm{s}$ となっている. この 2 つの数值 $\left(2,500 \mathrm{~m}^{3} / \mathrm{s}\right.$, 2,100 $\mathrm{m}^{3} / \mathrm{s}$ ）が近いことは，1886 年の迅速測図における隅 田川の流路と川幅が現代と大きく違わないこととも符合 している. そこで本研究では日本堤システムに到達する 洪水ピーク流量を $2,500 \mathrm{~m}^{3} / \mathrm{s}$ と考えて汇濫数值シミュレ ーションを行うこととした.

次に国土交通省水文水質データベースに掲載されてい る 2007 年 9 月洪水の治水橋地点(41.9KP)におけるピーク 流量 $5,285 \mathrm{~m}^{3} / \mathrm{s}$ のハイドログラフ（図-7 の藍色）から洪 水波形を以下のように定めた。洪水体積（流量の時間積 分值 : $\left.V_{0}\right)$ を一定に保ったままピーク流量が $2,500 \mathrm{~m}^{3} / \mathrm{s}$ に なるよう時間軸を引き伸ばし Case1（赤色）の波形を作 成し，その時間軸をさらに 2 倍引き伸ばして Case2（緑 色）の波形を作成した.また観測波形と Case1 の中間と して，洪水体積を保ったままピーク流量が $4,000 \mathrm{~m}^{3} / \mathrm{s}$ に なるように縦軸と横軸を調節した波形（水色）を Case3 とした．以下では Case1 を基準条件とし，Case2 で洪水 継続時間の影響を, Case3 で洪水ピーク流量の影響を調 ベる. なお河道のマニング係数は鮏川ら ${ }^{8)}$ を参考に 0.025 とし，汇濫原のマニング係数も河道と同じ 0.025 とした. また河口水位は潮汐等により変動するが，日本堤システ ムの基本機能を調べるという目的から、本研究では東京 湾平均海面位（T.P. $\pm 0.0 \mathrm{~m}$ ）で一定であるとした.

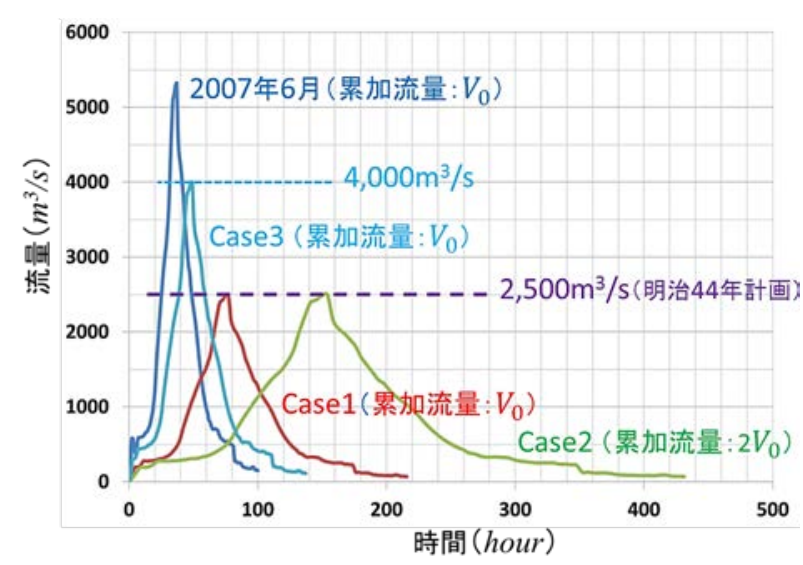

図-7 洪水流量波形 


\section{4. 数值シミュレーションの結果}

\section{（1）Case1（基準条件）における汇濫特性}

図-8 のハイドログラフに縦線で示す 4 時点での 汇濫分布と氾濫水深を図-9に示す. 水路は赤で, 堤防は黒で示している.

氾濫は上流域から始まり，66 hour（増水期）で 湾曲部内岸に氾濫しているが，74 hour（流量ピー ク前）までは千住堤によって西側の区域への拡大が 抑えられている。安政江戸図（図-1(a)）によれば 千住堤西側には奥州・日光街道の枝道（あるいは旧 道）があるので，千住堤はその浸水を防ぐ意味があ ったと推察される.また綾瀬川合流点から遡った水 が熊谷堤北側に氾監し，中川に通じる水路から溢れ た水が墨田堤裏側を浸水させる。前述したように， これらの地域は水田であった。

78 hour（流量ピーク時）では千住堤下流側から 回り込んだ汇濫水により上述の枝街道の部分は水没 する. 110 hour（減水時）には上流部と日本堤北側 の汇濫水深は減じるが，熊谷堤北部と中川西側の低 地の汇濫域は拡大している.ただし後者の浸水範囲 は小堤の付近までであり，本所などの市街地には到 達しておらず，最終的には中川から排水されたと考 えられる。

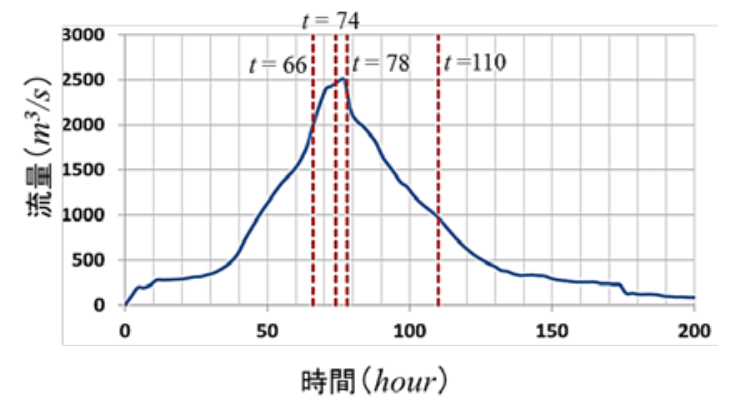

図-8＼cjkstart流量波形と計測時間（Case1） (a) $t=66$ hour (増水期)

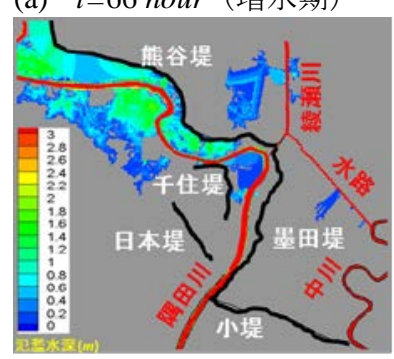

(c) $\mathrm{t}=78$ hour (ピーク時)

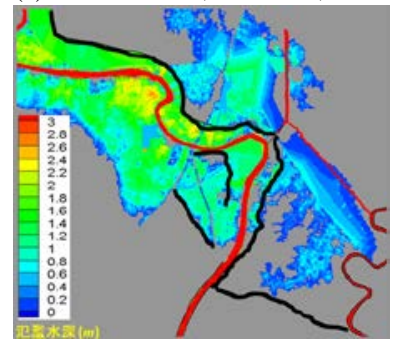

(b) $t=74$ hour (ピーク前)

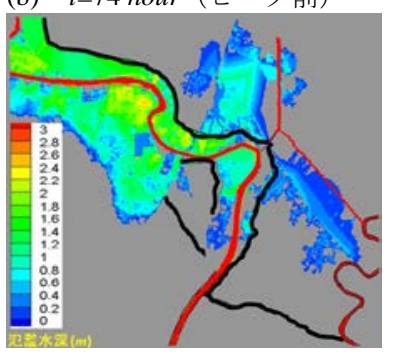

(d) $t=110$ hour (減水時)

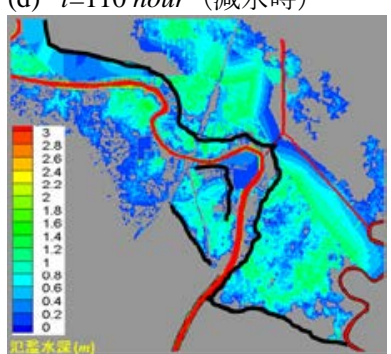

図-9 氾濫域の拡大（Case1）
以上の結果から，日本堤システムの上流側の広い 汇濫原で洪水が効果的に貯留されていることがわか る。また同時に綾瀬川を逆流する水により熊谷堤北 部と中川方面の農地にも氾濫が及んでいる。一方, 日本堤より南側の隅田川下流部の流れはどのように なっているか. 次にそれを調べた。

図-10 は各時点の水収支を表している。“流入量” とは計算区間上流端の流量, “隅田川への流出量” と は，日本堤下流の隅田川河道への流出量である. “綾瀬川への逆流量” とは，綾瀬川合流点を遡る流量 で，熊谷堤北部と中川方面への汇濫水となる量であ る。“合計流出量”とは隅田川下流および綾瀬川への 流出量の合計である。“貯留速度”は流入量と合計流 出量の差から計算したもので，日本堤から上流の隅 田川汇濫原における汇濫量の変化速度に対応する. 減水期には貯留量が減るのでマイナスとなる.

この図から，貯留速度に比較して合計流出量が大 きいことがわかる．特に隅田川下流への流出の割合 が大きい。この理由は水位縦断分布から理解できる

（図-11）。日本堤において $2 \mathrm{~m}$ 程度の水位上昇が 発生するが，江戸時代の隅田川河口は現在の河口か ら約 $2 \mathrm{~km}$ 上流にあり，そこでの水位は一定（平均 海面）である。そのため，下流河道の水面勾配は平 常時に比べて著しく大きくなり，その結果として流 速が増大して流出量が増える。これが日本堤システ ムの隠された水理効果であったと考えられる。

\section{（2）Case2（継続時間の長い洪水）での汇濫特性}

図-12 に示す 4 時点での氾濫分布と汇濫水深を図 -13 に示す. Case1 に比較して時間スケールが 2 倍 になり，累加流量も 2 倍になっているので，氾濫水 深は多少増えているが，氾濫域も広がっているため 水深増加量はそれほど大きくない。この理由は日本 堤での堰上げによって流出量も増加することによる。

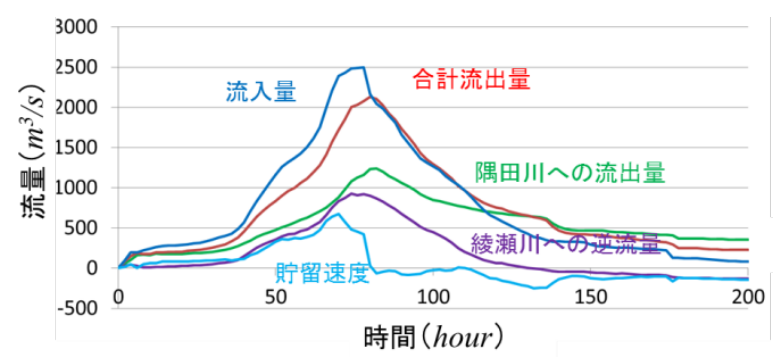

図-10 水収支の計算結果（Case1）

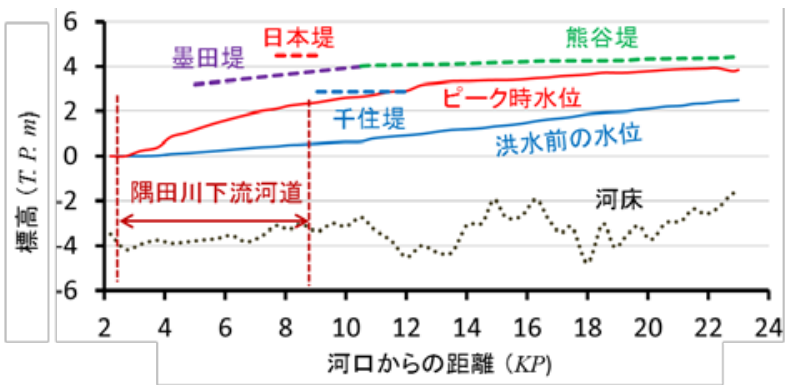

図-11 ピーク時の隅田川水位縦断形（Case1） 


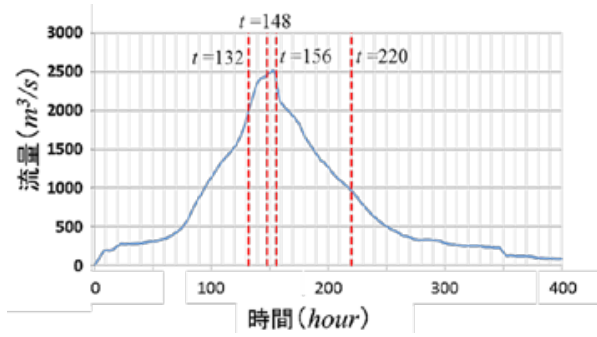

図-12 流量波形と計測時間（Case2）

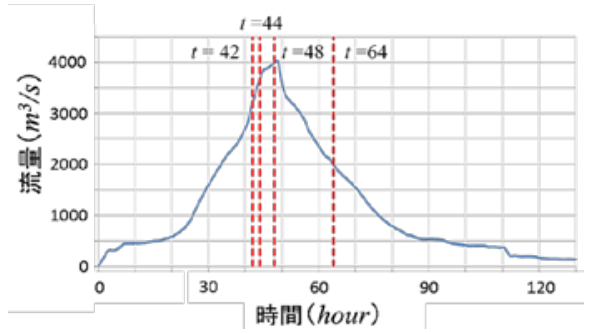

図-14 流量波形と計測時間（Case3）
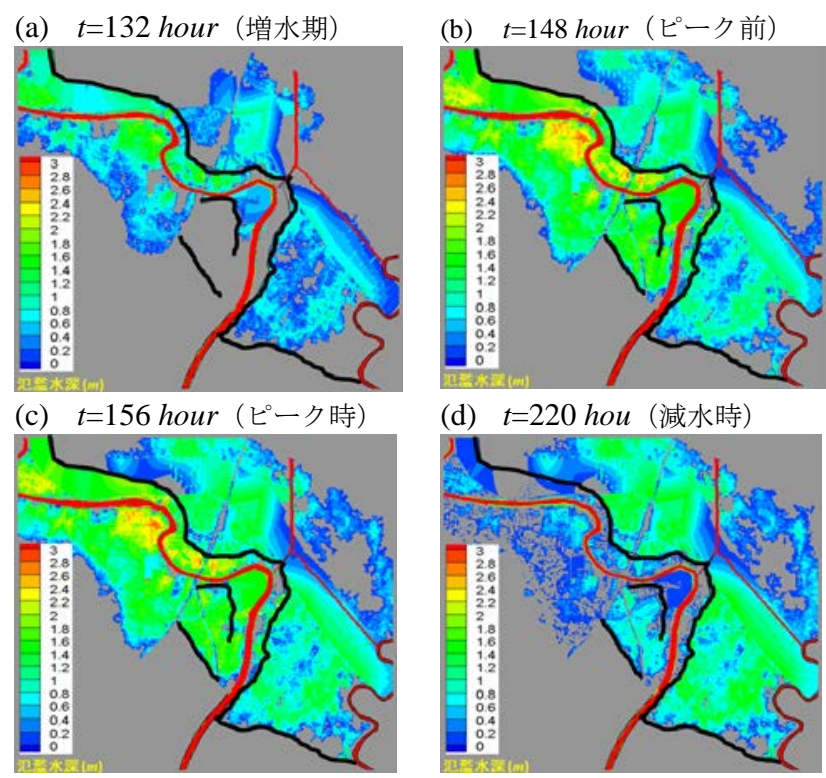

図-13 氾濫域の拡大（Case2）

すなわち，日本堤は貯留施設であると同時に，北 部・東部への汇濫域の拡大と隅田川下流部の流速増 大を誘起する装置であると言える．現代の調節池の ように貯留機能を主体とした遊水地の場合は，洪水 継続時間が長くなると満杯になってしまって機能を 失うが，貯留とともに流出量が増加する日本堤シス テムの場合は, 洪水継続時間が長くなっても効果が 持続する. また流出増によって水位上昇が抑えられ るため, 日本堤を越水する恐れが少なくなる.

\section{（3） Case3（大きなピーク流量）での汇濫特性}

図-14 に示す 4 時点での汇濫分布と汇濫水深を図 -15 に示す. 洪水ピーク前の 44 hour において日本 堤と墨田堤の間の漏斗状のエリアは満杯となり, 洪 水ピークの 48 hour では日本堤下流（浅草地区）に 汇濫が及んでいる.この汇濫水は奥州・日光街道を 越水したもので，日本堤本体は越水しておらず，下 流側水深は上流側に比較してかなり小さい.

Case3 の洪水体積は Case1 と同じなので，貯留機 能を主体とした遊水地では両ケースで同様の効果が 見られるはずだが，堰上げによる流出量増加を見込 んだ日本堤システムにおいては, 流出による汇濫域 の拡大が追いつかなくなっているのである.

このことは, 日本堤システムが，上流部の氾濫に よって洪水波形が平滑化されているという当時の荒 川の状況を前提とする施設であったことを示唆して (a) $t=42$ hour（増水期）

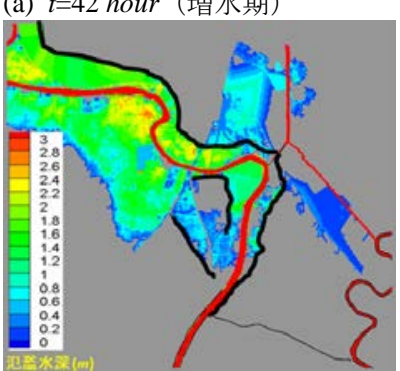

(c) $t=48$ hour (ピーク時)

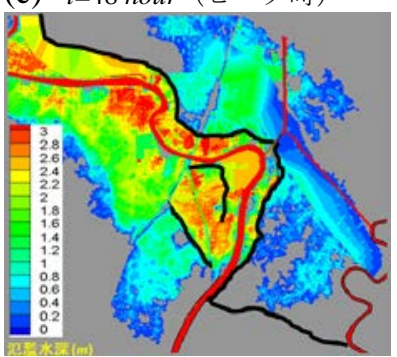

(b) $t=44$ hour $(ヒ ゚ ー ク$ 前 $)$

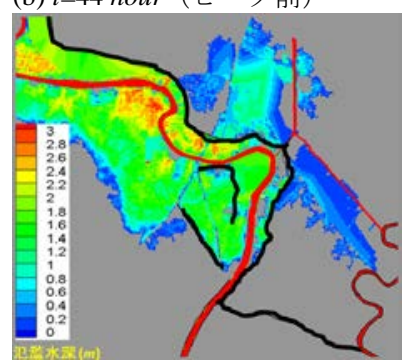

(d) $t=64$ hour（減水時）

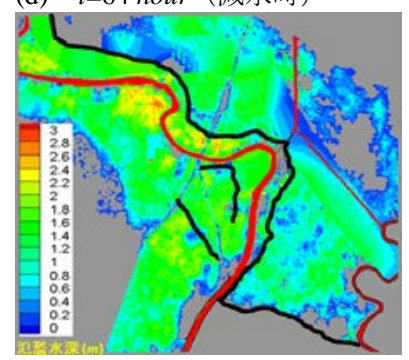

図-15 汇濫域の拡大（Case3）

いる. 実際，明治 44 年策定の直轄河川計画におけ る岩淵地点の計画比流量 $q$ (計画洪水量 $Q_{p} /$ 流域面 積 A）は $1.17 \mathrm{~m}^{3} / \mathrm{s} / \mathrm{km}^{2} \quad\left(Q_{p}=2,500 \mathrm{~m}^{3} / \mathrm{s}\right.$ として計算 $)$ であり, $q=\alpha \cdot A^{-0.8}$ という経験的関係式 ${ }^{7)}$ における係 数 $\alpha$ が当時の 13 の直轄河川中最低となっていた.

\section{5. 穴あき遊水地}

従来の研究では, 日本堤の機能を“上流側での貯 留”と考えていた（図-16(a)）。しかし図-10 に示 した水収支計算の結果からすると，主たる機能は堰 上げによる隅田川下流への流量増と, 北部および東 部の農地への氾濫水誘導であったと思われる（図一 16 (b)）。このような設計思想は，昨今建設される ようになった流水型ダム（穴あきダム）に通じると ころがある。穴あきダムでは貯水位の上昇とともに 流出量が自然に増加する。流量波形によっては貯水 池体積を十分使い切ることができないという久点は あるものの，ダム堤体の安全性は向上するので，監 理職員が不要になるというメリットがある.

そこで穴あきダムとの類似性から日本堤を「穴あ き遊水地」として見た場合，“第一の穴” は日本堤 と墨田堤が作る狭窄部である。これにより隅田川下 流への流出量は比較的小さな水位上昇で増加しうる。

“第二の穴” は綾瀬川合流部である．江戸時代以 前には綾瀬川上流部に荒川洪水が流入することもあ 
(a) 貯留型遊水地

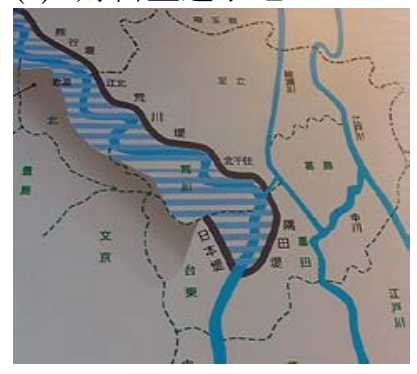

(b) 穴あき遊水地

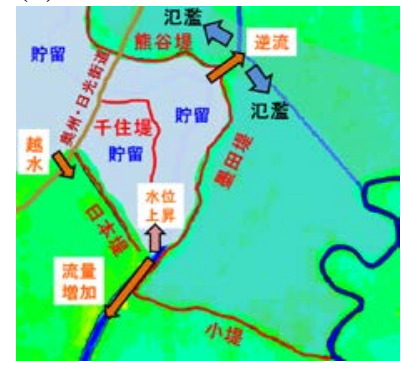

図-16 日本堤システムの機能に関する 2 つの解釈

ったが ${ }^{3)}$ ，荒川西遷以後は，綾瀬川はおとなしい緩 流河川になった。 またその中流部はほとんど農地で あるので，荒川洪水の一部を逆流させて遊水させた ことも考えられる. 一方、綾瀬川合流点近傍から中 川に至る水路（古綾瀬川）は水運を目的としていた が，洪水時には荒川から中川低地に洪水を導く放水 路としての役割を担っていた可能性がある. この水 路に流れ込んだ水は, 図-9(d), 図-13(d), 図一 15 (d) に示したように隅田川と中川の間を江戸湾に 向かって流下することになる。 そこで水戸下屋敷か ら中川に向から水路の北岸に小堤を築いて氾濫水が 南流するのを防いだのではないかと考えられる.

Case3 のピーク流量時（図-15(c)）には，日本堤 北西端の奥州・日光街道で水深 $20 \mathrm{~cm}$ 程度の溢水が 生じている。このとき日本堤本体では越水は生じて いないが，上流側水位は天端にかなり近づいている. したがって，この部分が “余水吐”として日本堤の 越水破堤を防ぐ役割を果たしていたかもしれない. ただし本計算で用いた標高データが街道部分の微地 形をそこまで表現できているから゙うかはわからない.

\section{6. おわりに}

以上の検討から，日本堤システムは「穴あき遊水 地」であつたというのが本研究の結論である.ただ し Case2 と Case3 の比較からわかるように，このよ うな遊水地は洪水波形が緩やかである場合にのみ効 果を発揮する。 3 (4) で述べたように，明治 44 年の
全国直轄河川の治水計画で荒川の比流量が他河川に 比較して小さかったことから，日本堤は上流域での 汇濫を前提として成立していたと推察される。

ところで堤（つつみ）という言葉は“長い盛土” を意味し，その代表が河川堤防であるが，“防”の 字を付けることにより「堤防のラインから手前には 水を絶対に入れない」という強い意志が感じられる. しかし江戸時代の堤の規模を考えれば、「堤に沿っ て外水を誘導する」という設計思想ではなかったか と思うのだが，どうであろうか．つまり堤がつくる 水位変化を利用して洪水を誘導するという考えであ る、筆者はこの治水方式に対して「柔能く剛を制 す」という“カッコよさ”を感じるのである.

謝辞：本研究は河川財団の研究助成（課題番号： 27-1212-006）を受けている。また国土交通省関東 地方整備局荒川下流河川事務所および東京都建設局 河川部から資料の提供をいただいた．記して謝意を 表する. なお本研究は東京工業大学名誉教授吉川秀 夫先生から頂戴したご示唆がきっかけとなって行わ れた．褁心より感謝申し上げる.

\section{参考文献}

1) 国土交通省荒川下流工事務所：荒川放水路変遷誌, 2011.

2) 宮村忠：日本の水害史と堤防，予防時報，245, pp.4247, 2011.

3) 国土交通省荒川上流工事務所 : 荒川の歴史一江戸時代, http://www.ktr.mlit.go.jp/arajo/arajo00031.html.

4) 赤穗良輔, 石川忠晴 : 平成23年東北地方太平洋沖地震 津波における利根川下流の津波遡上再現計算, 土木学 会論文集B1(水工学), 68(4), pp.I_1543 -I_1548, 2012.

5) 石川忠晴, 赤穂良輔 : 数值シミュレーションによる江 戸期百間川放水路の洪水調節機能の評価, 土木学会論 文集B1(水工学), 72(4), pp.I_343 -I_348, 2016.

6) 国土地理院: 基盤地図情報数值標高モデル(5mメッシ ᄀ ), http://fgd.gis.go.jp/download/menu.php

7) 山本晃一：河川計画の技術史，山海堂，1999.

8)鮏川登ほか（1989）：隅田川のながれに関する考察, 土木学会年次講演会, 44(2), pp.212-213.

(2016. 9. 30 受付)

\section{NUMERICAL STUDY ON THE FLOOD CONTROL CAPABILITY OF NIHON- TSUTSUMI SYSTEM IN EDO PERIOD}

\section{Tadaharu ISHIKAWA, Ryosuke AKOH and Yuki KOBAYASHI}

A series of numerical flow simulation was conducted to investigate the flood control function of Nihon-Tsutsumi bank system, which was constructed in the $17^{\text {th }}$ century to prevent inundation in Edo City. Ground elevation of floodplain and bank hights of the day were estimated from a survey map of early $20^{\text {th }}$ century, and flood hydrographs for the flow simulation were assumed being based on the flood discharge written in the flood prevention plan of early $20^{\text {th }}$ century and a recent flood data. The simulation results showed that the effect of damming up by the bank system was to increase the downstream flow from the system, and to induce the water flow to the paddy in adjacent rural areas, rather than the flood flow reduction by the water storage on the floodplain upstream from the bank system. The flow simulation also suggested that the possibility of bank overflow was not large due to the increase of downstream flow and the expansion of inundation area at the time of high waterstage in the bank system area. 